\title{
A Probe into the Moral Education in College English Teaching
}

\author{
Jia Mengshan \\ School of Foreign Studies, Jiangxi Science \& \\ Technology Normal University, \\ Nanchang 330038, China
}

\author{
Tang Xiao \\ School of Foreign Studies, Jiangxi Science \& \\ Technology Normal University, \\ Nanchang 330038, China
}

\begin{abstract}
College English is a general compulsory course which lasts longest in the period of higher education. It means that College English teachers are the ones who contact with their students most often and influence their students most deeply. Every teacher bears the responsibility of teaching and educating, and moral education should be integrated into College English teaching. College English teachers should have strong consciousness of professional ethics, explore the ideological content of teaching materials, design teaching procedures, and guide students to have ideological journeys of some familiar daily life or some influential social events with flexible teaching methodologies.
\end{abstract}

Keywords- College English teaching; quality-oriented education; moral education; comparative principle

\section{Introduction}

Moral education is the most important component of quality-oriented education. The universality of exam-oriented education makes the arrangement of the specialized courses center around the examination throughout the country, and thus education turns out to be pure knowledge impartment. Under such circumstances, College English teaching can hardly escape from the blight of the exam-oriented education. College English is one of the compulsory courses in most Chinese universities and it is a course displays a perfect fusion of multi-discipline knowledge, such as, Linguistics, Pedagogy, Psychology, and so on, which makes College English a interdisciplinary course with rich moral education contents. This study is based on the status of the moral education in College English teaching. As for how to fully explore the materials on moral education and how to bring the function of moral education into full play, some fundamental investigations have been performed in the hope that we may achieve the goal of educating people in the process of imparting knowledge.

\section{Current Situation of Moral Education in College English Teaching}

The Universities of Oxford and Cambridge in Britain believe that cultivating an educated person is more important than imparting knowledge, and they hold the belief that the achievement of education is human being rather than books, and the method of education should be diversified, not single.

In fact, back in 2004, the State Council of China clearly pointed out in Opinions on Further Strengthening and Improving College Students' Ideological and Political Education: "Courses in colleges of higher education have the function of cultivating people, all the teaching staff are responsible for moral education... Explore the ideological and political resources of all kinds of courses. Strengthen the ideological and political education in the course of imparting professional knowledge, and let students consciously 
strengthen ideological and moral cultivation and improve the political consciousness when learning scientific and cultural knowledge."

In any of China's universities, College English is the most far-reaching and the most widely spread compulsory course. Among all the required courses, College English is a general compulsory course which lasts longest in the period of higher education, and it is also a course experienced most frequent teaching reforms. However, whatever kind of teaching reform is implemented, it could not escape centering on language teaching, combining with different kinds of teaching method reform so as to improve students' listening, speaking, reading, writing, translating and other comprehensive skills as well as students' self-learning ability. Many college English teachers focus on imparting language knowledge and the training of language skills, and pay little attention to the cultural differences between China and western countries and the negative influence of the teaching material's content, not to mention positively guide students' ideology and morality. Even the current College English teaching reform based on the teaching content hardly involves the ideological connotations of the teaching materials. In fact, if the teaching materials are not properly guided to students, some negative effects may grow.

Ways of cultivation should be diversified, not single. And it's more important to understand the two words "educate people" if we really want to do a good job "teaching". Students' mastering professional knowledge and skills doesn't mean teachers' completing the educational work. In addition, education includes guiding students to form the correct outlook on life and world outlook, and helping them develop a good character. Not only college counselors or head teachers, moral course teachers, but all the staff in colleges and universities bear students' ideological and moral education work. It means that college English teachers take responsibility for students' ideological and moral education.

\section{Principles of Moral Education in College English Teaching}

\subsection{Ideological Principle}

German educator Herbart believed that teaching without moral education was only a means without purpose, and moral education without teaching was only a purpose without means. Hence, we need to pay special attention to the ideological content of College English teaching materials and fully exert its function of moral education. Moral education contents and factors should permeate classroom teaching, even very abstract natural science courses contains many moral education factors. "For example, the spirit of exploration, the spirit of innovation, the spirit of seeking truth and not being afraid of sacrifice and the like are advocated by natural science research. Above all, humanities and social sciences contain rich contents of moral education." [ 11

Not a single course or educator can achieve the goal of moral education. In America, many universities carry out ideological and moral education through classroom teaching, and attach great importance to general education curriculum. China has taken general education curriculum into account in recent years. Since College English is a general compulsory course which lasts longest in the period of higher education, college English teachers bear the responsibility to help achieve the goal of moral education. "According to Piaget's subject and object thought of genetic epistemology, the teaching material of English is not a simple information container, but a reflection of the author's intention, value orientation, will, and even thought under the cross-cultural background." ${ }^{21}$ It is a requirement 
of quality education for English educators to make moral education integrated into College English teaching. College students should not only learn English knowledge, but also develop good moral quality so as to achieve the aim of educating people. The selection of College English teaching content is the key to achieve this goal. "When writing and selecting English learning material, as well as making the courseware, college teachers should take the contents of ideological and political education seriously, and pay attention to individual behaviors, and teaching process may exert subtle influence on college students' ideology. "[3]

\subsection{The Principle of A Combination of Cultures}

The Origin and development of the English language is inseparable from the related English culture. "Although culture moral education lays emphasis on its cultural attributes, it more emphasizes the cultural awareness of the moral education function under the guidance of cultural values and practical activities embodying moral education function on the basis of cognition." ${ }^{[41}$

Chinese traditional culture is suffering an unprecedented impact and challenge of foreign culture. Teachers should combine related English culture when teaching English language knowledge, and try to avoid aphasia of Chinese culture in College English class. Teachers need to carefully design classroom teaching according to the teaching contents, and take heed of combining Chinese traditional culture, helping students form an objective and rational attitude to analyze problems and not to take a one-sided approach to problems.

\subsection{Comparative Principle}

In College English class, many teachers are limited to the introduction of relevant English countries' culture and thought, and they seldom make a comparison with Chinese culture and thought, which is easy to let students believe that western ideas are generally superior to theirs. Teachers may design classroom activities based on teaching materials. For example, on the basis of the principle of cooperation between teachers and students, compare Chinese and Western thoughts related to teaching to explore their similarities and differences together. The comparison and contrast of Chinese and western cultures and thoughts may help students realize that we cannot make a subjective judgment over whether one is better than the other, and most of the time we need to analyze problems under different cultural backgrounds. Furthermore, students can learn more about not only western culture, but also the essence of Chinese traditional culture in the comparison and contrast.

\subsection{The Principle of Being Close to Life}

The principle of being close to life, namely, according to the characteristics of college students' physical and psychological development, convey cultural thoughts by using plain life language and ways that college students can easily understand and accept to achieve a kind of imperceptible result. To be close to life, teachers must avoid using difficult and uncommon language as well as long and tedious sermons. Being close to life also means the ideological content of teaching should be close to the times and reality. It requires that teachers and students should create a relaxed and lifestyle classroom atmosphere together to improve students' ideological and moral accomplishment when helping students improve their knowledge of the English language.

\section{Conclusion}

College English teachers contact with their students most often and influence their students most deeply. Every teacher bears the responsibility of teaching and educating, and 
moral education should be integrated into College English teaching. College English teachers should have strong consciousness of professional ethics, explore the ideological content of teaching materials, design teaching procedures, and guide students to have ideological journeys of some familiar daily life or some influential social events with flexible teaching methodologies. In addition, teachers should be good at teaching reflection and teaching by personal example as well as verbal instruction.

\section{ACKNOWLEDGMENT}

This work is supported by the 2014 Jiangxi Science Education Project in General: On the Correlation between College English Teaching and Moral Education (Item Number: 14YB069)

\section{References}

[1] Sun Ming. The Plight of the Moral Education Work in Colleges and Universities and Its Countermeasures [J]. Journal of Hubei University (Philosophy and Social Science), 2004, (1): 106.

[2] Gan Huali. The Value Meaning of College English Teaching with Subject and Object Thought of Genetic Epistemology [J]. Guangxi Journal of Light Industry, 2013, (47): 141.

[3] Li Tianyi. An Enquiry into College Students' Ideological and Moral Cultivation in the Context of Multiple Modes [J]. Hubei Social Sciences, 2013, (8): 180.

[4] Lu Lin. Exploring the Culture Moral Education Mode, Promoting the Innovation of Moral Education [J]. Henan Social Sciences, 2011, (5): 156. 